\title{
Mass mortality event in red coral Corallium rubrum populations in the Provence region (France, NW Mediterranean)
}

\author{
J. Garrabou*, T. Perez, S. Sartoretto, J. G. Harmelin \\ Centre d'Océanologie de Marseille, UMR-CNRS 6540 DIMAR, Station Marine d'Endoume, Rue Batterie des Lions, \\ 13007 Marseille, France
}

\begin{abstract}
A mass mortality event of the red coral Corallium rubrum (L.) occurred in the NW Mediterranean region in summer 1999. The main objectives of the present study were to document the mortality suffered by the red coral populations in the Provence region and assess ecological correlates of the mortality which could help to identify the putative agent or agents of the event. The mortality outbreak resulted in partial to complete loss of the coenenchyme. The first observations of red coral mortality in the study area were in early October 1999 and continued until November 1999. To determine the extent of mortality on red coral populations, the incidence (= \% colonies suffering mortality) and the virulence (= \% coenenchyme loss) were quantified. Twelve surveys were carried out from November 1999 to January 2000. A total of 874 colonies of the 2375 observed showed some mortality. Incidence and virulence differed significantly among surveys. In some cases about $80 \%$ of the colonies were affected, while in others only $5 \%$ of colonies showed some mortality. Depth had a strong influence on the incidence of mortality. Shallower populations had the greatest incidence, while populations deeper than $30 \mathrm{~m}$ depth showed no mortality. However, virulence was similar in the 10 to $30 \mathrm{~m}$ depth range. With regard to habitat, the entrances of caves displayed a significantly higher incidence but not virulence than the interiors. Given the life history traits of red coral (mainly slow growth and low recruitment), it seems that recovery from the outbreak will be a long-term process. However, further studies are urgently required to provide basic information regarding red coral population dynamics as a basis for hypotheses on the actual recovery capability of affected populations. The cause of the mass mortality is unknown. However, during late summer 1999, the NW Mediterranean area affected by the mass mortality event experienced high temperatures and hydrographic stability over a period of several weeks. This temperature anomaly could have caused physiological stress or/and triggered the development of pathogenic agents that otherwise would have remained non-virulent. This hypothesis is reinforced by the absence of signs of mass mortality below $30 \mathrm{~m}$ depth in red coral populations. Since the NW Mediterranean seems to be affected by the global warming trend, if the temperature hypothesis is confirmed, the long-term consequences of a repetition of this kind of event could severely endanger the persistence of shallow-water red coral populations.
\end{abstract}

KEY WORDS: Mortality · Tissue loss $\cdot$ Corallium rubrum $\cdot$ Global change $\cdot$ NW Mediterranean benthos

\section{INTRODUCTION}

The Mediterranean red coral, Corallium rubrum (L.) (Gorgonacea: Octocorallia), is essentially found in the

*E-mail: garrabou@com.univ-mrs.fr western basin of the Mediterranean Sea, although some populations have been reported in the eastern basin and off the Atlantic coasts of Africa (Marchetti 1965, Zibrowius et al. 1984, Chintiroglou et al. 1989). Red coral grows on cave walls, vertical cliffs and overhangs at 10 to 200 m depth (Laborel \& Vacelet 1961, Weinberg 1978).

(C) Inter-Research 2001 
Red coral populations have long been commercially exploited, mainly for use in jewellery. Intensive harvesting has caused a severe depletion of most commercial stocks (Santangelo et al. 1993). In spite of being a commercial species, little is known of the biology of red coral. The few studies available depict red coral as a long-lived species (decades) with a slow growth rate (Lacaze-Duthiers 1864, Harmelin 1984, Garcia-Rodriguez \& Masso 1986a, Abbiati et al. 1992, Allemand 1993). Red coral is a dioecious species, with short-lived planula larvae (Vighi 1972, Weinberg 1979a). It seems that red coral colonies reach maturity at a young age ( 2 to 3 yr) (Abbiati et al. 1991). Although highly variable, recruitment rates appear to be relatively low, except when new space becomes available through harvesting (Santangelo et al. 1997, Linares et al. 2000). These last 2 features have prevented the disappearance of red coral from harvested areas.

Besides human harvesting, natural sources of mortality of red coral include competition for space with sponges and other sessile biota, dislodgement from the substrate due the action of boring species (Harmelin 1984) or seismic movements (Di Geronimo et al. 1994), predation by the small gastropod Pseudosmnia carnea and the crustacean Balssia gasti (Abbiatti et al. 1992), and sedimentation increase. In general, these factors usually appear to have a limited impact on red coral populations.

A mass mortality event affecting red coral occurred in the NW Mediterranean region in summer 1999.

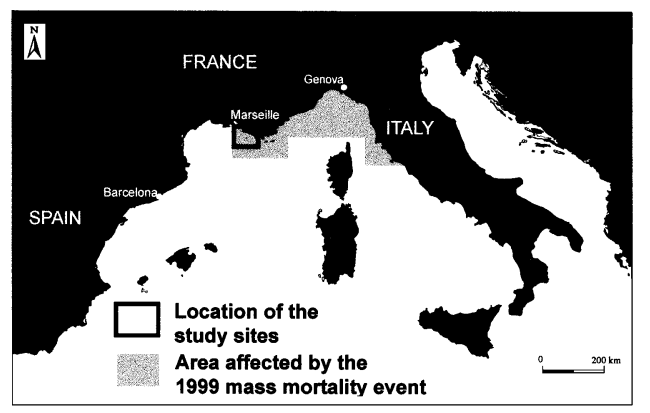

Fig. 1. Area affected by the 1999 mass mortality event and location of the red coral (Corallium rubrum) study sites in Provence, France

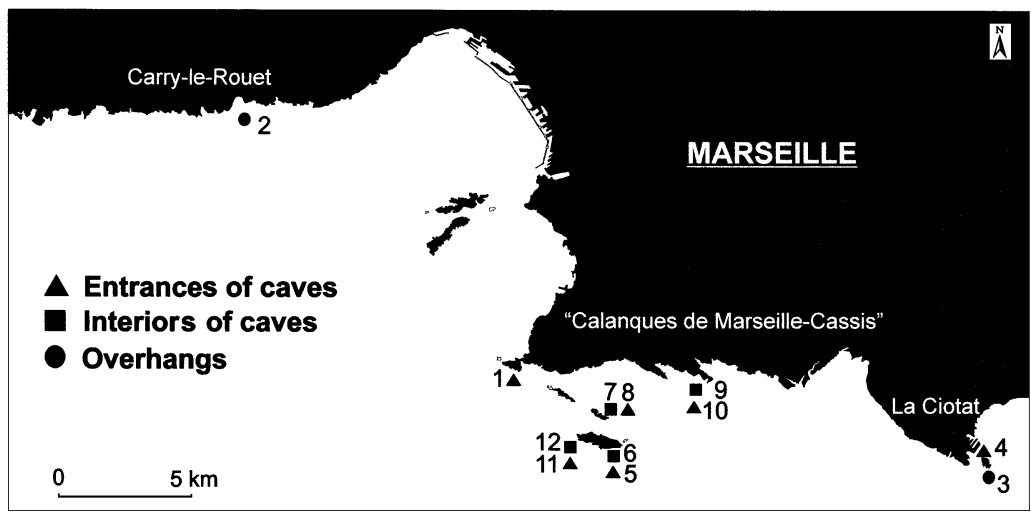

Besides red coral, 27 other species of marine invertebrates including gorgonians (Paramuricea clavata, Eunicella singularis, E. cavolinii) and sponges (e.g. Spongia officinalis, Cacospongia scalaris) were affected (Cerrano et al. 2000, Perez et al. 2000). Populations of sessile invertebrates were affected along the NW Mediterranean shore from the Bay of Genoa in Italy to the Bay of Marseilles in France. The range of coastline affected may in fact have been even more extensive, since complete information from southern Italy and from the southern and eastern parts of the Mediterranean was unavailable. The only 2 precedents for recent mass mortality events of sessile biota documented for the Mediterranean concerned deep populations ( 80 to $200 \mathrm{~m}$ ) of red coral and gorgonians along the coast of Provence in 1987 (Rivoire 1991, Arnoux et al. 1992), and sponge populations in the western and eastern basins of the Mediterranean in 1986 to 1990 (Vacelet 1990). Thus, taking into account the number of species affected and the geographic scale, the 1999 mass mortality event could be considered as the biggest event of this kind ever recorded for Mediterranean coastal habitats. The putative agent of the mortality has not been identified. It seems, however, that a temperature anomaly registered during late summer 1999 (Perez et al. 2000, Romano et al. 2000) could be either a main factor, causing physiological stress, or a triggering factor, favoring the development of pathogenic agents. Various studies are under way to identify the possible causes of the outbreak.

The objectives of the present study were to document mortality suffered by the red coral populations in the Provence region and to assess ecological correlates of the mortality which could help to identify the putative agent or agents of the event. Finally, the density and size structure of 6 red coral populations were quantified to provide demographic insights into the effects of and recovery from the mass mortality.

\section{MATERIALS AND METHODS}

Study area. The study sites are located along the rocky coast between Carry-le-Rouet, west of Marseille, and La Ciotat, covering a distance of about $50 \mathrm{~km}$ (Fig. 1). This region is characterized by the frequent occurrence of submerged cavities and overhangs at shallow depths which favors the development of Corallium rubrum (Laborel \& 
Vacelet 1961). Most of the shallowwater $(<25 \mathrm{~m}$ depth) populations from the Mediterranean French coasts are concentrated in this area (Laborel \& Vacelet 1961).

Mortality incidence and virulence. Most red coral colonies have a typical erect growth habit with fairly developed branching. However, colonies with a wide encrusting base and several erect branches may occur. In our study, each upright branch was counted as a unit, since enumeration of encrusting parts was not always possible because of the high density of branches and overgrowth over the encrusting parts. However, when possible, we also noted when branches belonged to the same encrusting base.

Our data showed that each sample comprised at least 100 distinct colonies. For greater clarity, we will here use the term 'colony' to refer to an individual branch.

To determine the extent of mortality on red coral populations in the Provence region, data on the incidence (i.e. percentage of colonies affected: dead or suffering partial mortality) and the virulence (i.e. degree of mortality within each colony) were noted. Virulence was estimated as the percentage of tissue loss (coenenchyme) according to 5 classes from 10 to $100 \%$ $(10-24,25-49,50-74,75-99,100 \%)$. In affected colonies, the condition of the skeletal axis was classified into 1 of 3 categories: (1) denuded axis, (2) recent epibiosis (e.g. hydroids, small serpulid polychaetes) or (3) ancient epibiosis (e.g. encrusting bryozoans or sponges). Twelve surveys were carried out to quantify the extent of mortality from November 1999 to January 2000 using SCUBA diving. In each survey, a minimum of 100 colonies were sampled, with more than 2000 colonies observed overall. During each survey the state of colonies was recorded along a random punctuated strip transect (width 10 to $15 \mathrm{~cm}$ ). To avoid bias resulting from possible patchiness of mortality, observations of 5 to 10 colonies were made at non-contiguous, randomly distributed sections of the transect. The initial and final depths of the transect were noted to calculate the average depth for the survey.

Surveys to quantify the extent of mortality were restricted to sites shallower than $30 \mathrm{~m} \mathrm{(13} \mathrm{to} 26 \mathrm{~m}$; Table 1). However, we made 14 observations of populations deeper than $30 \mathrm{~m}$ (30 to $60 \mathrm{~m}$ ) that documented the absence of mass mortality below this depth (Perez et al. 2000). Furthermore, because of the urgency of the data collection, we decided to concentrate our efforts of quantification on the affected populations. Seven sites were selected with the aim of encompass- ing the full range of habitats inhabited (entrances and interiors of the caves and overhangs) by the shallow red coral populations in Provence (Table 1).

Population structure. The density and the size of colonies were recorded in 2 habitats at 3 sites (Table 1) together with the assessment of mortality rate. Density was measured in randomly placed $16.5 \times 16.5 \mathrm{~cm}$ quadrats. At least 20 quadrats were sampled, resulting in a total sampled area of about $0.5 \mathrm{~m}^{2}$ per survey. The size structure of the red coral populations was assessed by measuring the height of all colonies $(2 \mathrm{~mm}$ accuracy) within the quadrats used for density assessment. Finally, permanent marks were made on the rocks near the areas sampled to relocate areas surveyed for future monitoring. These data provide baselines on density and size structure, as well as making it possible to explore the relationship between size and degree of tissue loss.

Statistical analysis. Because of the low colony numbers for some categories of degree of tissue loss, data were pooled into 3 new categories: dead (100\% tissue loss), affected (from 10 to $99 \%$ tissue loss), and nonaffected ( 0 to $10 \%$ tissue loss). Homogeneity tests were used to determine differences in incidence and virulence between surveys and the possible effect of depth, habitat and colony size. To examine incidence (frequency of colonies suffering whole or partial mortality), homogeneity tests took into account 2 categories: the sum of dead and affected colonies versus the number of unaffected colonies. For the virulence analysis, homogeneity tests compared the different frequencies of affected and dead colonies. Since the goal of these analysis were to identify the putative agent or agents of the mass mortality, data from Carryle-Rouet were not taken into account in the analysis because this site showed no sign of mass mortality. 


\section{RESULTS}

\section{Description of mortality}

Mortality in Corallium rubrum resulted in partial to complete loss of the coenenchyme, and thus in partial to complete denudation of the axial skeleton of colonies, without apparent loss of skeleton material (Fig. 2). Necrosis location did not follow any specific pattern, i.e. lesions were observed in all parts of the colonies from the tips to the bases. The first observations of red coral mortality in the study area were recorded in early October 1999 and continued until November 1999, when the outbreak stopped.

\section{Incidence and virulence of mass mortality}

$40.2 \%$ of colonies (874 of the 2174 colonies observed in the affected sites) showed some mortality. In the geographic range examined there were great differences in the incidence of the mortality between surveys. In some surveys, about $80 \%$ of colonies were affected, while in others only $5 \%$ of colonies showed some mortality (Fig. 3). These differences were statisti-

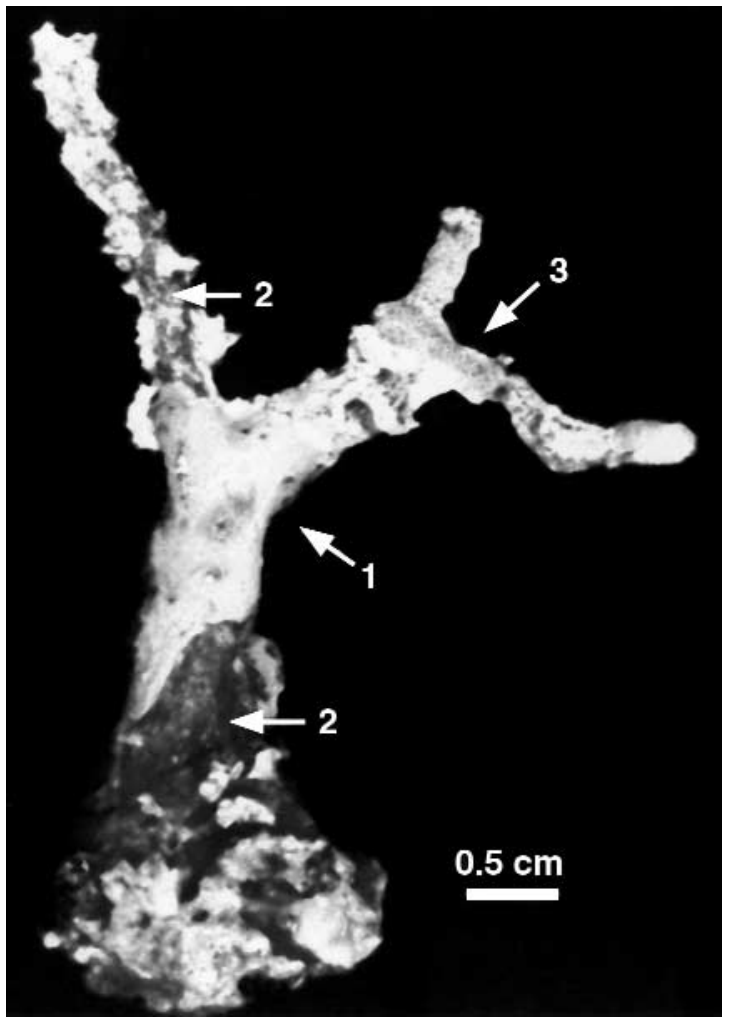

Fig. 2. Corallium rubrum. Colony affected by mortality 6 mo after the outbreak. 1: coenenchyme; 2: denuded axis; 3: epibiont organism

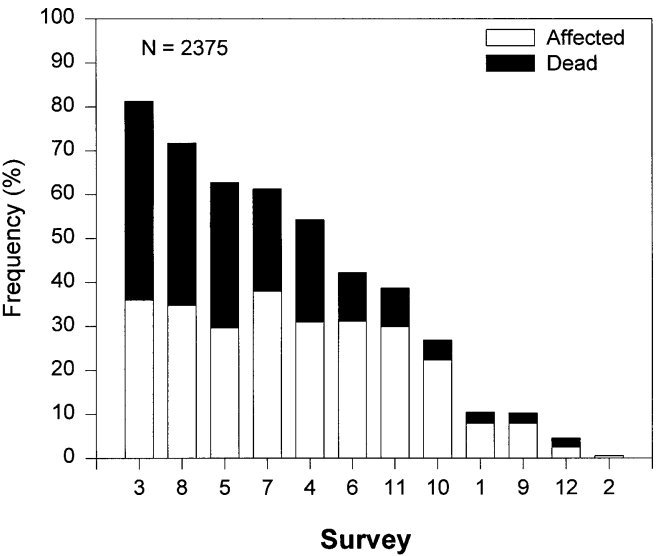

Fig. 3. Corallium rubrum. Mortality and partial mortality. Frequency of dead and affected colonies during each survey. Surveys numbered as in Table 1

cally significant $\left(\chi^{2}=590.0 ; \mathrm{df}=10 ; \mathrm{p}<0.001\right)$. It is remarkable that only Carry-le-Rouet was not affected by the 1999 mortality event. Virulence was also highly variable, as reflected by the proportions of colonies totally dead and those suffering partial mortality, which varied widely between surveys (Fig. 3). The differences were again statistically significant $\left(\chi^{2}=\right.$ 63.8.5; $\mathrm{df}=10 ; \mathrm{p}<0.001$ ).

\section{Epibiosis of colonies}

In most colonies suffering partial or total mortality, colonisation of the denuded axis by macroscopic biota was lacking or limited to pioneer stages such as foraminiferans, hydroids, spirorbs or small serpulids; only $6 \%$ of the affected colonies displayed later stages of colonisation (e.g. sponges, large serpulids and thick bryozoan colonies) corresponding to necroses initiated long before summer 1999 (Fig. 4).

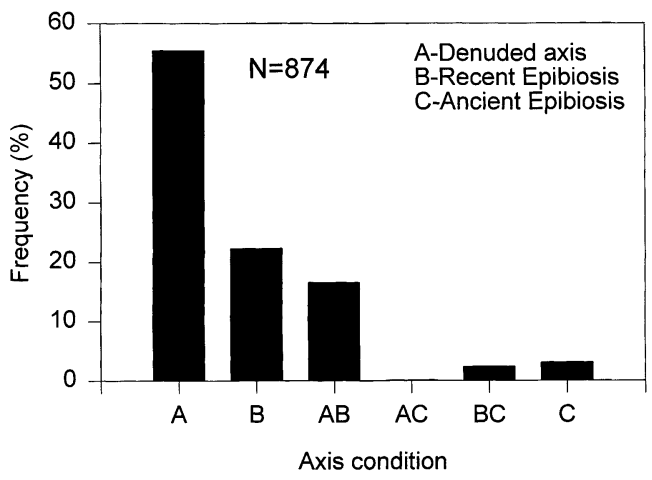

Fig. 4. Corallium rubrum. Condition of axis in colonies at surveyed sites. Data pooled from all surveys 
Table 2. Corallium rubrum. Height $(\mathrm{cm})$ and density (number of colonies per $272.2 \mathrm{~cm}^{2}$ ) for 3 caves surveyed

\begin{tabular}{|c|c|c|c|c|c|c|}
\hline \multirow[t]{2}{*}{ Site } & \multicolumn{3}{|c|}{ Height } & \multicolumn{3}{|c|}{ Density } \\
\hline & Mean $\pm \mathrm{SD}$ & Range & $\mathrm{N}$ & Mean $\pm \mathrm{SD}$ & Range & $\mathrm{N}$ \\
\hline \multicolumn{7}{|l|}{ Figuier } \\
\hline Entrance & $3.8 \pm 1.7$ & $0.2-10$ & (331) & $16.5 \pm 7.6$ & $5-33$ & (20) \\
\hline Interior & $2.2 \pm 1.3$ & $0.1-6$ & (166) & $7.9 \pm 4.5$ & $1-16$ & (21) \\
\hline \multicolumn{7}{|l|}{ Moyade } \\
\hline Entrance & $2.7 \pm 1.6$ & $0.3-10$ & (137) & $6.2 \pm 5.3$ & $1-27$ & $(22)$ \\
\hline Interior & $1.6 \pm 0.9$ & $0.2-10$ & (196) & $7.5 \pm 6.3$ & $0-23$ & (26) \\
\hline \multicolumn{7}{|c|}{ Grotte Pérès } \\
\hline Entrance & $3.9 \pm 0.2$ & $0.3-9.5$ & $(279)$ & $13.3 \pm 5.5$ & $2-25$ & (21) \\
\hline Interior & $2.3 \pm 1.2$ & $0.2-7.0$ & (266) & $12.7 \pm 8.2$ & $5-36$ & (21) \\
\hline
\end{tabular}

obtained for 6 populations (Table 2). Density ranged from 6.2 colonies per $272 \mathrm{~cm}^{2}$ (i.e. 228 colonies $\mathrm{m}^{-2}$ : Moyade cave interior) to 16.5 colonies per $272 \mathrm{~cm}^{2}$ (i.e. 606 colonies $\mathrm{m}^{-2}$ : Figuier cave entrance; Table 2).

The lowest mean heights were found in the interiors of the 3 caves surveyed (1.6 and $2.3 \mathrm{~cm}$ ), while the highest mean heights values were recorded in the entrance of the caves of Figuier and Grotte Pérès $(\sim 4 \mathrm{~cm}$ : Table 2). Maximum and minimum colony heights were 10 and $0.2 \mathrm{~cm}$ respectively. Height distribution followed a log-normal pattern in most

In general, the condition of the axes was fairly homogenous within surveys, i.e. most axes at any site were either denuded or recently colonized. However, large intersite differences in axis condition were observed (data not shown), probably reflecting timing of the onset of mortality, local recruitment conditions (e.g. cryptic versus open habitats), and availability of propagules capable of colonizing the denuded axes.

\section{Environmental factors which could affect development of the mass mortality event}

Depth. To examine the effect of depth, data were pooled into 2 depth ranges: 10 to $20 \mathrm{~m}$ (6 surveys) and 20 to $30 \mathrm{~m}$ ( 5 surveys). There were no statistical differences in incidence or in virulence between the depth ranges examined (Fig. 5 ; incidence: $\chi^{2}=1.8$; $\mathrm{df}=1 ; \mathrm{p}=$ 0.2 ; virulence: $\chi^{2}=1.7 ; \mathrm{df}=1 ; \mathrm{p}=0.2$ ). However, red coral populations deeper than $30 \mathrm{~m}$ did not show any sign of damage. Unfortunately, data from these deep sites were not quantified due to field-work restrictions (see 'Materials and methods').

Habitat. To examine the possible effect of habitat, data were pooled into 2 groups: entrances (6 surveys) and interiors (4 surveys) of caves, and analyzed for differences in incidence and virulence. Incidence was significantly higher in the entrances of caves than in the interiors (Fig. $5 ; \chi^{2}=13.8$; df $=1$; p < 0.001). However, virulence was not significantly different, with similar proportions of dead and affected colonies in both habitats (Fig. $5 ; \chi^{2}=2.1$; df $=1 ; \mathrm{p}=0.2$ ).

\section{Population structure: density and colony size}

Besides degree of tissue loss and axis condition, measurements of colony density and height were study sites, with a peak within the 2 and $3 \mathrm{~cm}$ size classes and a progressive decline below and above this, up to $10 \mathrm{~cm}$ (Fig. 6).

\section{Effects of mortality on colony size}

Data on colony size were pooled into 3 size classes: $<3 \mathrm{~cm}, 3-6 \mathrm{~cm}$ and $>6 \mathrm{~cm}$. An homogeneity test revealed significant differences in the incidence and the virulence of mortality between size classes. Medium and large-sized colonies suffered higher incidence (about $45 \%$ of colonies) than small colonies (Fig. $7 ; \chi^{2}=31.5 ; \mathrm{df}=2 ; \mathrm{p}<0.001$ ). However, an inverse pattern emerged for virulence, with large colonies
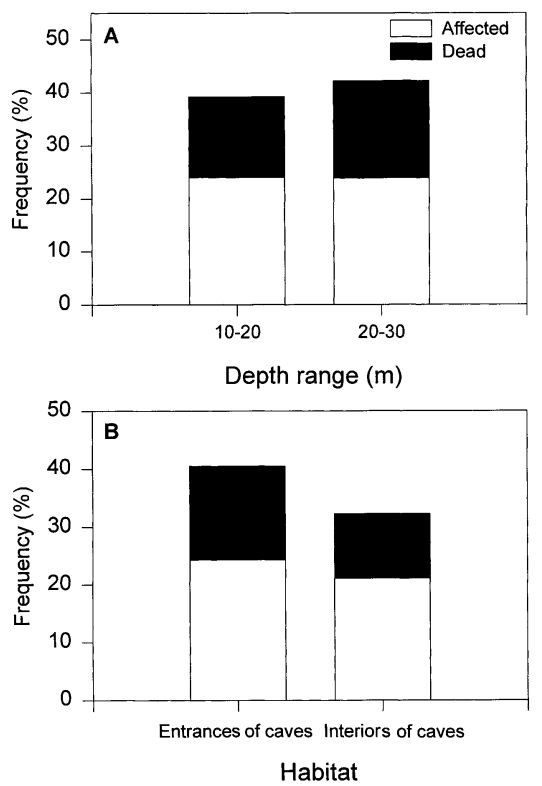

Fig. 5. Corallium rubrum. Effect of depth (A) and habitat (B) on mortality and partial mortality 

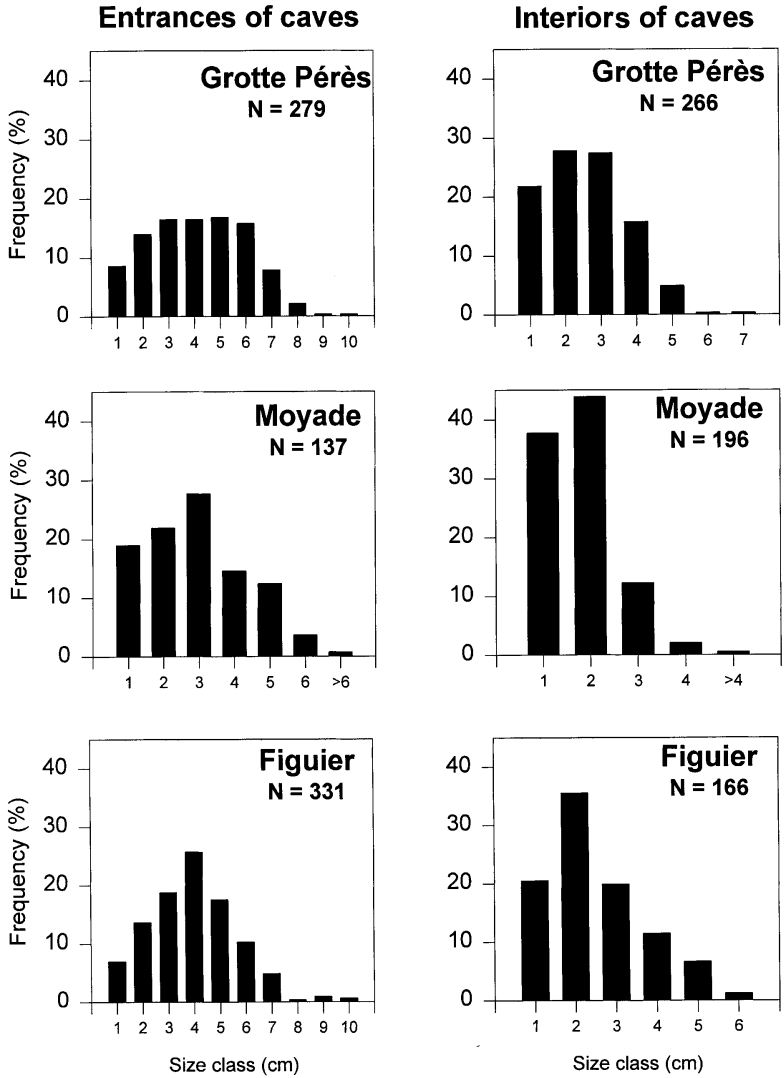

Fig. 6. Corallium rubrum. Height distribution frequencies at the 6 sites where height and density were measured (see Table 1)

showing the lowest virulence; only about $17 \%$ of colonies suffering complete mortality. Small colonies displayed highest virulence, with about $50 \%$ of damaged colonies suffering complete mortality. This difference in virulence was significant (Fig. $7 ; \chi^{2}=$ $26.4 ; \mathrm{df}=2 ; \mathrm{p}<0.001)$.

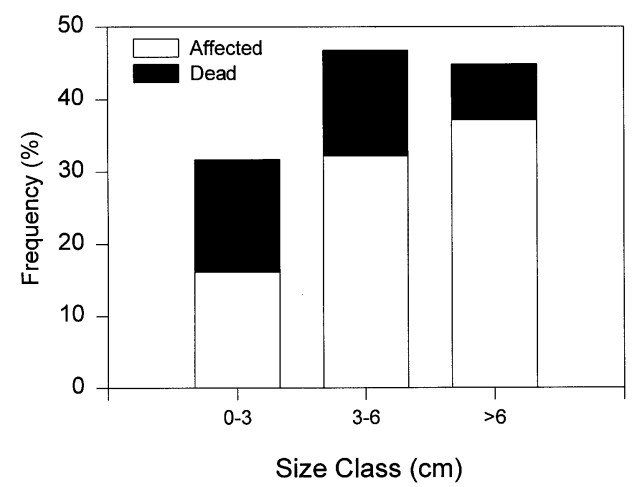

Fig. 7. Corallium rubrum. Effect of size on mortality and partial mortality. Data pooled from all surveys where size was measured (see Table 1)

\section{DISCUSSION}

\author{
1999 red coral mass mortality and recorded \\ precedents
}

The 1999 mass mortality event affected the Corallium rubrum populations at all sites surveyed along the $50 \mathrm{~km}$ of coastline in the Provence region, with the single exception of Carry-le-Rouet. The incidence and the virulence of the mortality were very heterogeneous between sites (Fig. 3). At affected sites, lowest incidence recorded was at least $10 \%$ of colonies. Unfortunately, no baseline data on the degree of necrosis in red coral were available for comparative analyses. However, most surveys were carried out in sites that are regularly monitored for other research purposes (e.g. natural heritage evaluation of Marseilles' coralligenous sites in 1998; Harmelin \& Sartoretto unpubl. data), and signs of exceptional mortality had never been noticed before the outbreak. For this reason, Carry-le-Rouet (site free of mass mortality) can be considered as a reference site for comparing degree of necrosis. At this site, only $0.1 \%$ of colonies showed partial mortality and no colony suffered complete mortality. These data strongly contrast with values from surveys of the other sites, underlining the dramatic effects of the 1999 mortality outbreak in the red coral populations.

Red coral from the other NW Mediterranean areas affected by the sessile invertebrate mass mortality event of summer 1999 also suffered mortality. Available information shows that shallow populations in the area around Nice (France) suffered extensive mortality (P. Francour pers. comm.). Further east, reports from the Gulf of Genoa (Cerrano et al. 2000) and Elba Island (Italy) indicated that populations were only marginally affected (G. Santangelo pers. comm.), probably because of their deeper distribution (30 to $35 \mathrm{~m}$ ). Finally, areas west of Marseille (beyond Cape Couronne), southern France, northwestern Corsica (Scandola) and northeastern Spain did not show any signs of mortality. The only recorded precedent of red coral mass mortality comparable in geographical range and virulence concerned deep populations (>80 $\mathrm{m}$ depth). This mass mortality was reported in 1987 in deep reefs between Marseille and Nice (Rivoire 1991, Arnoux et al. 1992). These observations were confirmed in 1990 by Arnoux et al. (1992). In shallow populations (above $20 \mathrm{~m}$ depth), the only case of extensive damage concerned a mortality event at La Ciotat in summer 1983 (Harmelin 1984).

\section{Consequences of the 1999 mass mortality}

Data on the population structure (density and size) of Corallium rubrum are scarce. The density of colonies 
at our study sites varied between 229 and 610 colonies $\mathrm{m}^{-2}$ (Table 2). These values are similar to (Marchetti 1965, Cattaneo-Vietti et al. 1992) or 2- to 6-fold higher than those reported for other areas of the NW Mediterranean (Marchetti 1965, Weinberg 1979b, Harmelin 1984, Cerrano et al. 1999, Linares et al. 2000), except for the population at Calafuria (Italy), where densities reached more than 1000 colonies $\mathrm{m}^{-2}$ (Santangelo et al. 1997, Cerrano et al. 1999). Data on height distribution reported here are close to those reported for similar habitats (Santangelo et al. 1988, Santangelo \& Abbiati 1989). As in the present study, Santangelo et al. (1988) found that height distribution followed a log-normal distribution pattern. Such pattern could result from harvesting pressure on the larger sized coral and/or recruitment limitation for the smaller-sized coral (see below).

Mortality had a differential impact, depending on colony size (Fig. 7). Incidence was lower in small colonies than in medium and large colonies. However, small colonies also suffered relatively higher virulence, showing higher whole-colony mortality rates (Fig. 7). It is thought that small colonies usually die completely or are not able to withstand damage arising from a disturbance event because they have fewer reserves of energy or materials to repair tissue loss (Connell 1973, Jackson 1979).

Basic information on red coral population dynamics, i.e. growth, reproduction, recruitment and post-settlement mortality, is even scarcer than on population structure. Therefore, it is difficult to hypothesize on the actual recovery capability of affected populations. However, the available data (see below) seem to indicate that recovery from the outbreak will be a longterm process.

\section{Growth}

Data on red coral growth are available for only a limited number of populations. Abbiati et al. (1992) and Garcia-Rodriguez \& Masso (1986b) estimated growth rates of 0.91 and $1.32 \mathrm{~mm} \mathrm{yr}^{-1}$ in diameter respectively. In situ measurements of young colonies over $4 \mathrm{yr}$ by Harmelin (1984) showed that the elongation rate of ramifications was $5.6 \pm 1.4 \mathrm{~mm} \mathrm{yr}^{-1}$. These growth rates emphasise the particularly slow growth of red coral in the habitats affected by the 1999 mass mortality event. On the basis of these data, we estimate that most colonies from the affected populations were at least 5 to 10 yr old.

On the one hand mass mortality could enhance the growth of colonies suffering little or no damage because of reduced intraspecific competition for food. On the other hand, growth in colonies with severe damage might be reduced because of the high energetic costs of extensive injury repair. Regeneration mechanisms can rapidly repair small lesions (e.g. 0.1 to $1 \mathrm{~cm}$ denuded axis). However, when lesions are greater, healing time increases proportionately to lesion size (van Woesik 1998, Bavestrello et al. 1999). Besides lesion size, the presence of fouling organisms, particularly at secondary successional stages, may considerably limit the likelihood of successful regeneration. Our surveys showed that more than $30 \%$ of affected colonies were already colonized by macroscopic organisms (Fig. 4). In June 2000, most affected colonies were colonized, indicating that regeneration was largely incomplete (J.G. et al. pers. obs.). In fact competitive interactions were observed between red coral and epibionts, as indicated by the presence of sweeper tentacles (usually related to competition; Lang \& Chornesky 1988) in polyps situated on the border between colonized axes and live tissue (Harmelin \& Garrabou unpubl. data). Competition with epibionts or the lack of sufficient energetic resources to repair damage could eventually cause the complete death of colonies initially suffering partial mortality, thus extending the effects of the mortality to periods after the actual mortality event.

\section{Reproduction and recruitment}

The only way for red coral populations to recover from a disturbance is through sexual recruitment, since Corallium rubrum has a limited capability for asexual reproduction (but see Russo et al. 1999). Short-term recovery of affected red coral populations through sexual reproduction seems difficult. Firstly, the reproductive capacity of colonies at severely affected sites would decrease by the extensive loss of living tissue due to whole and partial mortality. In clonal organisms, reproductive capacity is positively related to the amount of total living tissue (Hughes \& Cancino 1985). However, the higher survival rates of small colonies could favor recovery in this way, since these colonies could grow at higher rates and could be sexually mature at a relatively young age ( 2 or 3 yr old) (Abbiati et al. 1991). Secondly, the few data available indicate that the recruitment rate is rather low and highly variable between years. In non-harvested areas, it varied from 16 to 32 recruits $\mathrm{m}^{-2} \mathrm{yr}^{-1}$ between 1995 and 1999 (Linares et al. 2000) and from 0 to 12.5 recruits $\mathrm{m}^{-2} \mathrm{yr}^{-1}$ between 1979 and 2000 (Harmelin \& Garrabou unpubl. data). Furthermore, the height distribution pattern followed log-normal curves at most of our study sites, suggesting some limitation to recruitment in the populations examined. However, 
when new space becomes available through harvesting, recruitment rates may increase $\left(2000\right.$ recruits $\mathrm{m}^{-2}$ $\mathrm{yr}^{-1}$, Santangelo et al. 1997; 180 recruits $\mathrm{m}^{-2} \mathrm{yr}^{-1}$, Linares et al. 2000). These data may indicate that inter- and intraespecific competition for space is one of the main factors controlling the recruitment of red coral. During the 1999 mass mortality, however, no new space had become available for recruitment, since the dead colonies were still in place. Thirdly, red coral larvae have a low dispersal capability. Genetic studies on red coral populations have revealed high genetic heterogeneity on various spatial scales (from hundreds to tens of kilometers to meters) (Abbiati et al. 1993, 1999). Therefore, the possibility of populations recovery through settlement of larvae from non-impacted neighboring populations seems to be very unlikely.

From the above data, we conclude that recovery from the outbreak will be difficult, and it could well take tens of years for the affected populations to return to pre-mortality values. Furthermore, the ongoing harvesting of severely damaged populations could make recovery even longer. Harvesting itself removes large colonies (with high reproductive capability) from populations; however, since mortality affected all size classes, larvae supply and subsequent recruitment may be significantly reduced, ruling out the positive relationship between harvesting and recruitment. Nevertheless, since we lack reliable data on red coral population dynamics, it is difficult to predict population trajectories accurately. A major effort will be required to determine the variability in basic red coral population functions to better fit our predictions and eventually suggest management strategies to favor the population's recovery.

\section{Possible causes of mortality}

The cause of the mass mortality of red coral and the other 27 species affected during summer 1999 is unknown (Perez et al. 2000). Preliminary microbiological, biochemical and histological analyses carried out to identify potential pathogens or signs of physiological stress produced no conclusive results. As a general rule, identifying the cause of mass moralities and widespread diseases is very difficult. Analysis of about 12 diseases affecting cnidarians in the Caribbean Sea resulted in positive pathogen identification of only 3 (Harvell et al. 1999). Despite this, several microorganisms have been linked to widespread diseases: bacteria, fungi and protozoans. On the other hand, many large-scale mortality events have been related directly or indirectly to temperature increases (Harvell et al. 1999 and references therein). For in- stance, in coral reefs, a correlation between the occurrence of coral bleaching and high seawater temperature has been demonstrated (Glynn \& D'Croz 1990, Hoegh-Guldberg \& Salvat 1995, Berkelmans \& Oliver 1999). Likewise, it has been shown that the infection of a scleractinian species by a bacteria caused bleaching when the temperature was higher than normal (Kushmaro et al. 1996, 1997). During late summer 1999, the NW Mediterranean area affected by the mass mortality event experienced high temperatures and hydrographic stability for a period of several weeks (Perez et al. 2000, Romano et al. 2000). These climatic conditions resulted in an increase in seawater temperature during late summer 1999 of about $6^{\circ} \mathrm{C}$ at $20 \mathrm{~m}$ (from $17.3^{\circ} \mathrm{C}$ in 1998 to $23.1^{\circ} \mathrm{C}$ in 1999) and the descent of the thermocline from 20 to $25 \mathrm{~m}$ to $40 \mathrm{~m}$ depth (Perez et al. 2000, Romano et al. 2000). This temperature anomaly could have caused physiological stress to species (e.g. by increasing respiration rates), or/and triggered the development of pathogenic agents that otherwise would have remained non-virulent. The temperature hypothesis is reinforced by the absence of mass mortality below $30 \mathrm{~m}$ depth in red coral populations. However, since the whole area affected was submitted to the same temperature anomaly (Perez et al. 2000) and we found significant differences in the degree of mortality between surveyed sites, we must consider other factors besides temperature to explain the mass mortality event.

Our results have also shown the degree of mortality to be related to habitat. Populations in the interior of caves were less affected than those at the entrances (Fig. 5). Cryptic habitats could mitigate temperature changes occurring outside, and offer protection against exposure to pollutants and potential pathogens carried by currents. In the study area, the predominant general circulation off the Provence coasts follows an east to west direction (Northern or Ligurian current) (Ovchinnikov 1966, Millot 1979, Bethoux \& Prieur 1983). This differential mortality was related to a greater exposure to pollutants (Arnoux et al. 1992). On the deep rocky reefs affected by the mass mortality in the eigties (Rivoire 1991) red coral populations facing the Ligurian current showed higher mortality. Our surveys covered different orientations. However, since the main flow of the Ligurian current is interrupted by coastal topography, it was difficult for us to relate mortality patterns to current exposure. Thus, differences in incidence and virulence between surveys can be related to a differential degree of stress due to the temperature regime and chronic contamination that could have weakened host resistance to the agent(s) responsible for mortality. 


\section{Links between mass mortality and diseases and global change}

Mass mortality events and widespread diseases have increased during the last few decades in marine habitats worldwide (Harvell et al. 1999). This increase seems to be related to the global warming trend and anthropogenic stress (Harvell et al. 1999). Physical and biological evidence indicates that the NW Mediterranean is also being affected by global warming (Bethoux et al. 1990, 1998, Francour et al. 1994, Astraldi et al. 1995, Pascual et al. 1995). Thus, the mass mortality event affecting the red coral and the other invertebrate species could be part of a more general mortality process in marine habitats. The presumed linkage between the mortality outbreak and temperature suggests that new mortality events may occur in the same or other Mediterranean areas in the near future. According to this scenario, the persistence of Corallium rubrum in the shallow-water habitats appears very uncertain. Bearing in mind that it is almost entirely absent from the much warmer Eastern Mediterranean basin (especially in shallow-water habitats) (Chintiroglou et al. 1989, Barale 1999), red coral may not be able to survive in an environmental context of high seawater temperatures. Thus, the shallow-water habitats affected by mortality may be evincing one of the predicted ecological consequences of global warming: species disappearance and replacement (Hughes 2000). Therefore, we contend that monitoring programs of red coral populations and physico-chemical parameters should rapidly be set up to provide the necessary baselines to assess their recovery ability and to quantify changes in their environment. Such programs would serve as a basis for designing adequate management strategies (e.g. suspension of commercial harvesting in shallow waters), would provide further clues to the causes of mortality, and would help anticipate the risk of future outbreaks of mortality.

Acknowledgements. We thank B. de Ligondes, R. Graille and C. Jalong for their efficient and expert help in the field work which ensured excellent safety conditions during diving. We also thank 2 anonymous reviewers for valuable comments on the manuscript. This study was funded by the LITEAU programme (Ministère de l'Aménagement du Territoire et de l'Environnement de France) and partly by the PADI foundation and Communauté de Communes, Marseille Provence Métropole granted to J.G. was funded by a postdoctoral fellowship from the Ministerio de Educacion y Ciencia (Spain) and an EC Marie Curie Fellowship.

\section{LITERATURE CITED}

Abbiati M, Buffoni G, Dicola G, Santagelo G (1991) Red coral population dynamics: stabiltiy analysis and numerical simulation of time evolution of perturbed states. In: Ravera O (ed) Terrestrial and aquatic ecosystems: perturbation and recovery. Hellis Horwood, New York, p 219-228

Abbiati M, Buffoni G, Caforio G, Dicola G, Santangelo G (1992) Harvesting, predation and competition effects on a red coral population. Neth J Sea Res 30:219-228

Abbiati M, Santangelo G, Novelli S (1993) Genetic variation within and between two Tyrrhenian populations of the Mediterranean alcyonarian Corallium rubrum. Mar Ecol Prog Ser 95:245-250

Abbiati M, Novelli S, Harmelin JG, Santangelo G (1999) Struttura genetica di popolamenti simpatrici e allopatrici di corallo rosso. In: Cicogna F, Bavestrello G, CattaneoVietti R (eds) Biologia e tutela del corallo rosso e di altri ottocoralli del Mediterraneo. Ministero per le Politiche Agricole, Rome, p 5-21

Allemand D (1993) The biology and skeletogenesis of the Mediterranean red coral. Precious Corals Octocoral Res 2: 19-39

Arnoux A, Harmelin JG, Monod JL, Romaña LA, Zibrowius H (1992) Altérations des peuplements benthiques de roches profondes en Méditerranée nord-occidentale: quelques aspects biologiques et molysmologiques. C R Acad Sci Ser III Sci Vie 314:219-225

Astraldi M, Bianchi CM, Gasparini GP, Morri C (1995) Climatic fluctuations, current variability and marine species distribution: a case study in the Ligurian Sea (north-west Mediterranean). Oceanol Acta 18:139-149

Barale V (1999) Mediterranean coastal features from satellite observations. In: Özhan E (ed) Proceedings of the MEDCOAST 99-EMECS 99 Joint Conference, Land-Ocean Interactions, Vol 3: Managing Coastal Ecosystems, Antalya (Turkey), 9-13 November 1999. Middle East Technical University, Ankara, p 1899-1908

Bavestrello G, Cerrano C, Cattaneo-Vietti R, Zanzi D (1999) Epibiosi e mortalità in Paramuricea clavata nel Mar Ligure. In: Cicogna F, Bavestrello G, Cattaneo-Vietti R (eds), Biologia e tutela del corallo rosso e di altri ottocoralli del Mediterraneo. Red Coral and other Mediterranean Octocorals: Biology and Protection. Ministero per le Politiche Agricole, Rome, p 211-229

Berkelmans R, Oliver JK (1999) Large-scale bleaching of corals on the Great Barrier Reef. Coral Reefs 18:55-60

Bethoux JP, Prieur L (1983) Hydrologie et circulation en Méditerranée nord-occidentale. Pétrole Tech 299:25-34

Bethoux JP, Gentili B, Raunet J, Tailliez D (1990) Warming trend in the western Mediterranean deep water. Nature 347:660-662

Bethoux JP, Gentili B, Tailliez D (1998) Warming and freshwater budget change in the Mediterranean since the 1940 s, their possible relation to the greenhouse effect. Geophys Res Lett 25:1023-1026

Cattaneo-Vietti R, Cicogna F, Senes L (1992) I corallo rosso, una specie in pericolo? Boll Mus Ist Biol Univ Genova 56 57:195-207

Cerrano C, Bavestrello G, Cicogna F, Cattaneo-Vietti R (1999) Nuove esperienze sul trapianto e sugli effetti del prelievio di corallo rosso nel mar ligure. In: Cicogna F, Bavestrello G, Cattaneo-Vietti R (eds) Biologia e tutela del corallo rosso e di altri ottocoralli del Mediterraneo. Ministero per le Politiche Agricole, Rome, p 57-73

Cerrano C, Bavestrello G, Bianchi CN, Catteneo-Vietti R, Bava S, Morganti C, Morri C, Picco P, Sara G, Schiaparelli S, Siccardi A, Sponga F (2000) A catastrophic mass-mortality episode of gorgonians and other organisms in the Ligurian Sea (NW Mediterranean), summer 1999. Ecol Lett 3:284-293

Chintiroglou H, Dounas C, Koukouras A (1989) The presence 
of Corallium rubrum (Linnaeus, 1758) in the eastern Mediterranean Sea. Mitt Zool Mus Berl 65:145-149

Connell JH (1973) Population biology of reef-building corals. In: Jones OA, Endean R (eds) Biology and geology of coral reefs. Vol. 2. Academic Press, New York, p 205-245

Di Geronimo I, Rosso A, Sanfilippo R (1994) I banchi fossiliferi di Corallium rubrum al largo di Sciacca (Canale de Sicilia). In: Cicogna F, Bavestrello G, Cattaneo-Vietti R (eds) Il corallo rosso in Mediterraneo, arte, storia e scienza. Ministero Risarse Agricole Alimentari Forestali, Rome, p 75-107

Francour $\mathrm{P}$, Boudouresque CF, Harmelin JG, HarmelinVivien ML, Quignard JP (1994) Are the Mediterranean waters becoming warmer? Information from biological indicators. Mar Pollut Bull 28:523-526

Garcia-Rodriguez M, Masso C (1986a) Biometric study of Corallium rubrum (L.) populations from Gerona littoral (NE Spain). Bol Inst Esp Oceanogr 3:61-64

Garcia-Rodriguez M, Masso C (1986b) Some bases for the direct determination of age of Corallium rubrum (L.). Bol Inst Esp Oceanogr 3:65-74

Glynn PW, D'Croz L (1990) Experimental evidence for high temperature stress as the cause of El Niño-coincident coral mortality. Coral Reefs 8:181-191

Harmelin JG (1984) Biologie du corail rouge. Paramètres de populations, croissance et mortalité naturelle. Etat des connaissances en France. FAO Fish Rep 306:99-103

Harvell CD, Kim K, Burkholder JM, Colwell RR, Epstein PR, Grimes DJ, Hofmann EE, Lipp EK, Osterhaus ADME, Overstreet RM, Porter JW, Smith GW, Vasta GR (1999) Emerging marine diseases - climate links and anthropogenic factors. Science 285:1505-1510

Hoegh-Guldberg O, Salvat B (1995) Periodic mass-bleaching and elevated sea temperatures: bleaching of outer reef slope communities in Moorea, French Polynesia. Mar Ecol Prog Ser 121:181-190

Hughes L (2000) Biological consequences of global warming: is the signal already apparent? Trends Ecol Evol 15:56-61

Hughes RN, Cancino JM (1985) An ecological overview of cloning in Metazoa. In: Jackson JBC, Buss LW, Cook RE (eds) Population biology and evolution of clonal organisms. Yale University Press, New Haven, p 153-186

Jackson JBC (1979) Morphological strategies of sessile animals. In: Larwood G, Rosen BR (eds) Biology and systematics of colonial organisms. Academic Press, London \& New York, p 499-555

Kushmaro A, Loya Y, Fine M, Rosenberg E (1996) Bacterial infection and coral bleaching. Nature 380: p 396

Kushmaro A, Rosenberg E, Fine M, Loya Y (1997) Bleaching of the coral Oculina patagonica by Vibrio K-1. Mar Ecol Prog Ser 147:159-165

Laborel J, Vacelet J (1961) Répartition bionomique du Corallium rubrum Lmck dans les grottes sous-marines. Rapp PV Réun Comm Int Explor Sci Mer Méditerr Monaco 16: 464-469

Lacaze-Duthiers H (1864) Histoire naturelle du corail. JB Bailière et Fils, Paris

Lang JC, Chornesky EA (1988) Competition between scleractinian reef corals: a review of mechanisms and effects. In: Dubinsky Z (ed) Ecosystems of the world: coral reefs. Elesvier Press, Amsterdam, p 209-252

Linares C, Hereu B, Zabala M (2000) Avaluació de la població de corall Corallium rubrum de les illes Medes: exercici 1999. Seguiment temporal de la reserva marina de les illes Medes. Informe anual 1999. Departament de Medi Ambient, Generalitat de Catalunya, Barcelona

Editorial responsibility: Roger Hughes (Contributing Editor), Bangor, UK
Marchetti R (1965) Ricerche sul corallo rosso della costa ligure e toscana. II. Il Promontorio di Portofino. Rend Ist Lomb Sci Lett B 99:279-316

Millot C (1979) Wind induced upwellings in the Gulf of Lions. Oceanol Acta 2:261-274

Ovchinnikov IM (1966) Circulation in the surface and intermediate layers of the Mediterranean. Oceanology 6:48-59

Pascual J, Salat J, Palau M (1995) Evolution de la température de la mer entre 1973 et 1994, près de la côte catalane. Colloque scientifique OKEANOS 95: la Méditerranée, variabilités climatiques, environnement et biodiversité. Héliopolis, Montpellier

Perez T, Garrabou J, Sartoretto S, Harmelin JG, Francour P, Vacelet J (2000) Mortalité massive d'invertébrés marins: un événement sans précédent en Méditerranée nord-occidentale C R Acad Sci Ser III Life Sci 323:853-865

Rivoire G (1991) Mortalité de corail et de gorgones en profondeur au large des côtes provençales. In: Boudouresque

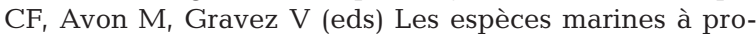
téger en Méditerranée. GIS Posidonies, France, p 53-59

Romano JC, Bensoussan N, Younes WAN, Arlhac D (2000) Anomalies thermiques dans les eaux du golfe de Marseille durant l'été 1999. Une explication partielle de la mortalité d'invertébrés fixés. C R Acad Sci Ser III Life Sci 323 415-427

Russo GF, Ulianich L, Cicogna F (1999) Autotomia e frammentazione, una nuova strategia riproduttiva per il corallo rosso. In: Cicogna F, Bavestrello G, Cattaneo-Vietti R (eds) Red coral and other Mediterranean octocorals: biology and protection. Ministero per le Politiche Agricole, Rome, p 45-55

Santangelo G, Abbiati M, Caforio G (1988) Structure of a red coral population. Rapp P-V Réun Comm Int Explor Sci Mer Méditerr Monaco 31: p19

Santangelo G, Abbiati M, Giannini F, Cicogna F (1993) Red coral fishing trends in the western Mediterranean Sea. Sci mar 57:139-143

Santangelo G, Bongiorni L, Buffoni G (1997) Recruitment density-dependence in red coral population. Biologia Mar Mediterr 97:277-281

Santangelo M, Abbiati M (1989) Il popolamento di Corallium rubrum (L.) di Calafuria: nota preliminare. Oebalia 15: $323-326$

Vacelet J (1990) Report of a mission in Tunisia, Syria, Cyprus, Greece and Turkey, 26 September-4 October and 25 October-12 November 1989 in the context of the programme 'Fight against the epidemic decimating sponges in the Mediterranean'. FAO Technical Cooperation. Programme, Rome

van Woesik R (1998) Lesion healing on massive Porites spp. corals. Mar Ecol Prog Ser 164:213-220

Vighi M (1972) Etude de la reproduction du Corallium rubrum (L.). Vie Milieu 23:21-32

Weinberg S (1978) Mediterranean octocorallian communities and the abiotic environment. Mar Biol 49:41-57

Weinberg S (1979a) The light-dependent behaviour of planula larvae of Eunicella singularis and Corallium rubrum and its implication for octocorallian ecology. Bijdr Dierkd 49:16-30

Weinberg S (1979b) Autoecology of shallow-water octocorallia from Mediterranean rocky substrata. I. The Banyuls area. Bijdr Dierkd 49:1-15

Zibrowius H, Monteiro-Marques V, Grasshoff M (1984) La répartition du Corallium rubrum dans l'Atlantique (Cnidaria: Anthozoa: Gorgonaria). Téthys 11:163-170

Submitted: August 30, 2000; Accepted: November 29, 2000 Proofs received from author(s): July 8, 2001 